\title{
NABOKOV'S DIALOGUE WITH CHEKHOV: LADIES WITH AND WITHOUT DOGS
}

\author{
KIRSTEN RUTSALA \\ University of Oklahoma \\ krutsala@ou.edu
}

\section{ABSTRACT}

Although Nabokov's admiration for Chekhov's work is well-documented, relatively little critical attention has been paid to the connections between the two writers' works. This article concentrates on two of Nabokov's stories as part of his larger dialogue with Chekhov. "The Reunion" is analyzed in conjunction with Chekhov's story "The Lady with the Little Dog," focusing on the theme of deception in both stories, particularly the notion of secret, double lives. The analysis also includes an examination of the stories' structural similarities, including the continual overturning of both characters' and readers' expectations. The expected endings do not occur in either story, and the ultimate conclusions are open-ended and ambiguous.

While "The Reunion" is a relatively straightforward story, "That in Aleppo Once. . . " is considerably more complex. Nabokov deliberately complicates matters by creating both an unreliable narrator and a second character (the narrator's wife) who invents stories about her experiences. Thus Nabokov takes Chekhov's ambiguity a step further: not only is the future of the characters uncertain, the past is as well. The Chekhovian subtext appears throughout the story, and it turns out that the story is a reversal or subversion of Chekhovian details and devices.

Perhaps most striking are the authors' respective treatments of their heroines. While Chekhov creates a character in Anna Sergeyevna who at first appears to be a literary type and then transforms her into a complex individual, Nabokov reverses this course. The narrator's wife continually evades his and the reader's understanding; the more we seem to learn about her, the less we really know. Finally, the narrator declares that his wife never existed at all, that she is simply "a phantom" who exists only on the page. From a metaliterary angle, of course, this is entirely accurate, since she is a fictional character. Thus Nabokov's story simultaneously pays tribute to Chekhov and lays bare the mechanics of storytelling, narrative decisions, and the creative process itself.

KEY WORDS: Nabokov, Chekhov, metafiction, parody, influence.

According to Harold Bloom, a central problem for any artist is repetition, the fear of discovering that his work is merely a copy or replica of an earlier artist's creation. Thus Bloom concludes that the covert subject of modern literature is the anxiety of influence, an expression of the notion that original creation is impossible because earlier texts possess primacy and therefore authority. Therefore true artists create their own text through a complex process of creative interpretation of earlier works. 
In Bloom's view, a successful literary work may be seen as a "strong misreading" of an earlier text or a "creative correction" (Bloom 1997: 29).

The anxiety of influence is especially pronounced in Russian literature. Due to geographical and cultural isolation, Russia's native literature lagged far behind the West for centuries. Well into the seventeenth century, Russia had virtually no secular art, literature, or music, and essentially remained "culturally medieval" (Terras 1991: 88). Peter the Great's sweeping reforms changed this situation, transforming virtually all aspects of Russian society via a systematic campaign of modernization and Westernization, which included an influx of translated literature. Early attempts at home-grown literature consisted of direct imitations of imported genres and conventions, often without adapting details to suit Russian reality and perhaps more importantly, without arising organically from the intellectual or social context of the country. The phenomenon of importing fully developed schools or traditions into Russia occurred frequently into the nineteenth century.

An English writer of the nineteenth century, for example, could look back on a long tradition of imaginative literature, from Chaucer to Shakespeare to Milton and beyond. Although bearing the weight of this heritage could be burdensome for English writers, as Bloom demonstrates, nonetheless they knew that this was their own tradition which they had rightfully inherited. For Russian writers, the anxiety of influence was perhaps even stronger. Not only were they conscious of the authority of previous texts of Western literature, they were also removed from this tradition, aware that it was imported from abroad and that they could not fully claim it as their own.

Pushkin's response to this fact of Russian intellectual life dramatically altered the landscape of Russian literature. First, he strove to fill the gap between Western and Russian literature by producing a vast range of texts in a variety of genres: lyric poems, narrative poems, short stories, historical fiction, drama, etc. At the same time, Pushkin moved beyond simply introducing new genres to the Russian reading public. He also experimented with literary conventions and engaged in metaliterary dialogue with his predecessors. Thus Pushkin coped with the anxiety of influence by constructing many of his texts as vehicles for commentary upon his literary predecessors and conventions. In this process, he helped transform and redefine these conventions. Pushkin may be seen as a central figure, even the founder, of two parallel literary traditions: classic Russian literature and self-conscious or metaliterary texts.

Born a century after Pushkin, Nabokov was highly conscious of his literary heritage. Russian literature constitutes a fundamental component of Nabokov's artistic vocabulary; quotations from and allusions to Russian literary texts form a crucial part of the fabric of Nabokov's works. These elements run the gamut from 
epigraphs to parallel scenes, parodic inversions of characters, shared imagery, and subversions of numerous details and devices. Nabokov reworks encoded literary and cultural material, challenges literary conventions and cultural assumptions, and in so doing lays bare the mechanics of the creative process. His literary interactions include responses to writers he admired unreservedly, as in the complex dialogue with and tribute to Pushkin that forms the basis of The Gift. Nabokov also engaged in a process of "creative struggle" with writers he vehemently disliked, such as Dostoevsky, whose works Nabokov dismissed categorically but nevertheless responded to artistically.

In Nabokov's report card of Russian prose, Chekhov ranks highly: he receives a solid A, together with Pushkin (only Tolstoy received an A+; Pushkin of course received an A+ for poetry). While Nabokov's praise for Tolstoy and Pushkin seems unqualified, he admits to some ambivalence in his admiration for Chekhov. He summarizes Chekhov's work rather dismissively as "a medley of dreadful prosaisms, ready-made epithets, repetitions, doctors, unconvincing vamps, and so forth." But, he adds, "it is his works which I would take on a trip to another planet" (Nabokov 1973: 286).

However, Nabokov's dialogue with Chekhov has received little critical attention. Simon Karlinsky, one of the few scholars who has explored this connection in depth, describes the link between Nabokov and Chekhov as a matter of "affinities that bind them and at the same time place them outside the traditions associated with Russian literature of the nineteenth and twentieth centuries" (Alexandrov 1995: 389). Among other correlations, he identifies the scientific background these two writers share, Chekhov's in medicine and Nabokov's in lepidoptera, and further suggests that their attention to precise detail and avoidance of generalizations may have their roots in this scientific training. Karlinsky argues that this perspective, translated into literary practice, helps account for the rejection of stereotype and formula that can be found in both writers' works.

Nabokov certainly absorbed a great deal about story-telling from Chekhov. The lack of didacticism in Chekhov's stories clearly appealed to Nabokov. As he notes in his Lectures on Russian Literature, in the course of analyzing the story "The New Villa," "Instead of making a character the medium of a lesson and instead of following up what would seem to Gorki, or to any Soviet author, a socialistic truth by making the rest of the man beautifully good. . instead of this, Chekhov gives us a living human being without bothering about political messages or traditions of writing" (Nabokov 1981: 289). Later in the same lecture, he points out that "Chekhov was the first among writers to rely so much upon the undercurrents of suggestion to convey a definite meaning" (Nabokov 1981: 251). Nabokov's admiration for "The Lady with the Little Dog" in particular is well documented. He sums up the story as follows: "All the 
traditional rules of story telling have been broken in this wonderful short story of twenty pages or so. There is no problem, no regular climax, no point at the end. And it is one of the greatest stories ever written" (Nabokov 1981: 262). Nabokov's approval is clearly linked to the fact that Chekhov has rejected formulaic literary patterns; it is "one of the greatest stories ever written" precisely because of Chekhov's risk-taking, not in spite of it. The overturning of established literary conventions forms the basis of the story's success, and it is not surprising that it is also at the heart of Nabokov's literary dialogue with Chekhov.

This essay includes brief commentaries on two of Nabokov's stories as part of his larger dialogue with Chekhov, and with "The Lady with the Little Dog" in particular. "The Reunion" (1931), called «Встреча» in Russian, takes place in Berlin in the early 1930's. Two brothers meet for the first time in ten years - one of them, Lev, emigrated from Russia after the Revolution, while the other, Serafim, remained in the Soviet Union and became a successful engineer. They were never close and now seem to have nothing in common, the political situation further overshadowing their strained conversation. Finally, a half-forgotten memory of their shared past provides a brief moment of connection between the brothers before they part ways. In his book, The World of Nabokov's Stories, Maxim Shrayer connects this story to a humorous Chekhov sketch, "Fat and Thin" («Толстый и тонкий»), on the level of plot (Shrayer 2000: 193). Nabokov may well have had this story in mind; the contrasts between the poor and thin Lev and his fatter, more prosperous brother are reiterated throughout the story. But the Chekhovian subtext seems to extend beyond this simple similarity in plots.

From a structural standpoint, this story recalls Chekhov's method of storytelling. As Nabokov says of Chekhov's approach, he "comes into the story 'The Lady with the Little Dog' without knocking. There is no dilly-dallying" (Nabokov 1981: 255). Nabokov applies the same technique. The main characters are immediately introduced: Lev and Serafim. Their backgrounds are sketched in with a few details. Their encounter is marked by a Chekhovian lack of genuine communication. Here too there is no "problem" or "climax" in the traditional sense. Although politics plays a role in the strain between the brothers, Nabokov does not seem interested in scoring political points or drawing a moral to the story.

The theme of deception in "The Reunion" recalls "The Lady with the Little Dog," particularly the notion of secret double lives. The adultery theme appears twice - Lev has recently separated from his wife after discovering her infidelity, and as a 17-year-old Serafim had a dramatic affair with a married woman which forms one of Lev's few vivid recollections of his brother. While adultery is at the foreground of "The Lady with the Little Dog," it is not the main subject of "The Reunion," and these details serve mainly to contribute to the atmosphere of secrecy and duplicity. For Lev, 
the deception works in two directions. On the one hand, he does not want his émigré friends to know about his meeting with his Soviet brother. When one of those friends telephones and invites him over, he lies about having "some unexpected business" («непредвиденное дело»). On the other hand, he is also untruthful to Serafim; he pretends that his telephone conversation was a "business call" («по делу»). This moment in particular seems like a parody of classic tales of infidelity - Lev recalls a husband who lies to both wife and mistress, a character perhaps not unlike Gurov in the days before he met Anna Sergeyevna.

The tension between public and private selves may be seen in both stories. Toward the end of "The Lady with the Little Dog," Gurov recognizes that his only sincere feelings take place in his "secret life" with Anna Sergeyevna:

He led a double life - one in public, in the sight of all whom it concerned, full of conventional truth and conventional deception, exactly like the lives of his friends and acquaintances, and another which flowed in secret. And owing to some strange, possibly quite accidental chain of circumstances, everything that was important, interesting, essential, everything about which he was sincere and never deceived himself, everything that composed the kernel of his life, went on in secret.

\begin{abstract}
У него были две жизни: одна явная, которую видели и знали все, кому это нужно было, полная условной правды и условного обмана, похожая совершенно на жизнь его знакомых и друзей, и другая - протекавшая тайно. И по какому-то странному стечению обстоятельств, быть может, случайному, всё, что было для него важно, интересно, необходимо, в чем он был искренен и не обманывал себя, что составляло зерно его жизни, происходило тайно от других.
\end{abstract}

Unlike Gurov, who clearly delineates his public and private selves, privileging the latter, Lev expresses ambivalence toward both his social circle in Berlin and his brother; he does not share his inner life with anyone. The conflicts and contradictions are not as easily divided between public and private selves, as they are for Gurov.

In addition, as in "The Lady with the Little Dog," the characters' and reader's expectations are continually overturned. Chekhov's story is so well known that I will mention just a few details that are particularly resonant in conjunction with Nabokov. Gurov and Anna Sergeyevna initially imagine themselves to be playing out conventional scenes, and the reader is lulled into believing that the story is a familiar tale. Before ever exchanging a word with Anna Sergeyevna, Gurov recalls the "stories of easy conquests" that circulate in Yalta and decides to play out the script of "a brief transitory liaison." Anna Sergeyevna believes herself to be in an entirely different sort of story, however. In the scene following the first time they make love, Anna is described as follows: "She assumed a pose of dismal meditation, like a repentant sinner in some classical painting" ("она задумалась в унылой позе, точно 
грешница на старинной картине"). She expects a conventional response from Gurov, evidently supposing that he will behave like a seducer from an old-fashioned story. Instead, Gurov is mildly surprised and ultimately bored by Anna Sergeyevna's acting "as if she had become a fallen woman." Neither character fully understands the story they have entered, so both reach for the comfort of standard plots.

Something similar occurs in "The Reunion." In the first part of the story, Lev imagines potential plots, complete with dialogue, as he prepares for his brother's arrival.

He imagines the formulaic conversation that might take place if Serafim were to meet his "impassioned and intolerant" émigré friends: “This is my brother, he's here from Russia.' ‘Pleased to meet you. Well, are they about to croak?' 'Whom exactly are you referring to? I don't understand.'" (Это мой брат, из России. - Очень приятно. Ну, что, - скоро они подохнут? - То есть кто - они? Я вас не понимаю.) Lev forestalls such an incident by concealing the meeting from his friends. Even the announcement in the first paragraph describing the fate of the two brothers (leaving Russia after the Revolution versus staying there and making accommodations to the Soviet state) as "a matter of pure chance" is something of a surprise. ("Дев уехал, Серафим остался, - и то и другое произошло совсем случайно.») Certainly for Nabokov's audience, the Russian émigré community, there could have been something faintly subversive about such a statement. Lev himself tries to rewrite these events later, summoning up outrage at his and Serafim's respective fates: "That Serafim could have preferred to my poverty, my purity, an active collaboration. . . and with whom, with whom!" (Что Серафим мог предпочесть моей бедности, моей чистоте - деятельное сотрудничество. . . с кем, с кем!) The effect of this outrage is certainly subdued by our awareness that the brothers' fates were the result of chance rather than active choice.

The actual meeting between the brothers goes much as Lev expected: a stilted and superficial conversation without any emotional connection. And yet, as with Gurov and Anna Sergeyevna, the expected ending does not occur. In "The Lady with the Little Dog," when the holiday ends and all (characters and reader alike) assume that the affair will end as well, Chekhov undercuts this expectation. The story continues, the love affair continues, and the narrative concludes at a moment of uncertainty, rather than resolution. The reader cannot predict the next scene; ironically but fittingly, the last words of the text read "it was clear to both of them that the end was still far off, and that what was to be most complicated and difficult for them was only just beginning" (обоим было ясно, что до конца еще далекодалеко и что самое сложное и трудное только еще начинается). Chekhov has in a sense extended the textual borders of the story. Similarly, "The Reunion," which has to this point followed the expected course, allows for a subtle shift. It is precisely at 
the point of departure that the two brothers have their only moment of genuine connection, when even their language shifts from clichés and stock phrases to more natural speech. Serafim looks at a picture on the wall, depicting a girl with a black poodle, and says, "Do you recall its name? Tikhotski used to visit us at the dacha with a girl and a poodle. What was the poodle's name?" Together, the brothers search their memories for the forgotten name. This also echoes a moment in "The Lady with the Little Dog," when Gurov travels to Anna Sergeyevna's town for the first time - he sees the familiar dog outside her house and tries to call it, but in his agitation, he has forgotten the dog's name. And in fact, Chekhov never does reveal the name of the little dog to the reader. Lev and Serafim part at the subway station, and Lev finally recalls the poodle's name: Joker ("Shutik" in Russian). The name itself underscores the tricks of memory and fate as played out in this story, and it may also hint at the writer's role as "joker," elaborately constructing a meeting between estranged brothers who are given the opportunity for a tenuous bond, but part ways before they can fully enjoy the pleasure of recollection and reconnection. While "The Lady with the Little Dog" ends with a moment that points to the future, "The Reunion" looks to the past, a past in which Chekhov plays a fundamental role. For the brothers, especially for Lev, a lady with a dog has become their connection to the past, to a Russia that no longer exists in reality, the Russia of Chekhov that is kept alive in literature and memory.

On the subject of dogs, it is interesting to note a further incidental connection between Chekhov and Nabokov. One of the Nabokov family's pet dachshunds, named Box II, was a grandson of Chekhov's dog, which had the equally improbable name Bromide (brother of Quinine). Although this link is, of course, simply coincidental, it does seem somehow appropriate that Nabokov, as a literary heir to Chekhov, should also have this tangible connection.

In another of Nabokov's stories, "That in Aleppo Once. .." (1947), the image of a lady and a dog appears again. While "The Reunion" is a relatively straightforward story, "That in Aleppo Once. .." is considerably more complex. This story is written in the form of a letter from a Russian émigré, who has just left Europe for the United States, to an acquaintance, an established Russian writer who is addressed merely as "V." It may be tempting for the reader to assume that "V" is actually Vladimir Nabokov, but practiced readers of Nabokov know that such assumptions are dangerous. The story's true subject seems to be an exploration of the process of telling stories, of constructing a narrative and transforming actual events into fiction. The narrator asks $\mathrm{V}$. to write a story based on his marriage and his journey from Paris in the wake of the Nazi invasion. However, Nabokov complicates matters by providing us with an unreliable narrator whose jumbled account includes numerous red herrings and wrong turns, and by the story's end it is impossible for the reader to 
know exactly what happened. Thus Nabokov takes Chekhov's ambiguity a step further; not only is the future of the characters uncertain, the past is as well.

Literary allusions abound in this story, particularly of course to Othello (the title, of course, is a quotation from Act V, scene ii: "Set you down this;/ And say besides, that in Aleppo once, /Where a malignant and a turban'd Turk/Beat a Venetian and traduc'd the state,/I took by the throat the circumcised dog,/And smote him thus"), and to Pushkin as well. The Chekhovian subtext also appears early in the story, when the narrator writes, "I come to you like that gushing lady in Chekhov who was dying to be described." As we progress through the narrative, it turns out that the story may be read as a reversal or subversion of numerous Chekhovian details and devices. This becomes apparent as the couple is fleeing Paris after the Nazi invasion, traveling south and trying to obtain visas to the United States. The narrator describes his wife in this way: "Oh, she bore it gamely enough - with a kind of dazed cheerfulness. Once, however, quite suddenly she started to sob in a sympathetic railway carriage. 'The dog,' she said, 'the dog we left. I cannot forget the poor dog.' The honesty of her grief shocked me, as we had never had any dog. 'I know,' she said, 'but I tried to imagine we had actually bought that setter. And just think, he would be now whining behind a locked door.' There had never been any talk of buying a setter." The detail of the forgotten dog, evoking a kind of automatic pathos, is pure invention. And yet this detail becomes emblematic, even the defining characteristic of the narrator's wife, who goes on to tell other stories about the tragic fate of her non-existent dog, including one version in which the narrator is said to have hanged the setter before leaving Paris. Thus she is the antithesis of Anna Sergeyevna: she is the lady without a dog.

The theme of deception and double lives appears here as well, when the narrator and his wife become separated during their journey. After a series of complicated mishaps, they are reunited, and she tells two stories about how she has spent the days without him. The first story involves joining with a group of fellow refugees, from whom she borrows money, and eventually makes her way to Nice. The other story consists of her spending several days with "a brute of a man" she met on the train. The narrator is outraged by her unfaithfulness and demands to hear all the details of the affair. But a few days later, she denies that the affair ever happened and returns to her original account of how she spent that time. She tells him, "You will think me crazy. . . but I didn't. Perhaps I live several lives at once. Perhaps I wanted to test you. Perhaps this bench is a dream and we are in Saratov or on some star." The mention of Saratov may be an allusion to Chekhov: Anna Sergeyevna lives in the provincial town of "S." which may be Saratov. At least one Russian film version of the story actually refers to the town as Saratov (Josef Heifitz's 1960 film). In a metaliterary sense, Nabokov is describing the process of composition, in which the 
writer imagines multiple possible outcomes for his story, revising the details and the narrative lines, providing his characters with "several lives at once."

At the end of the story, after the two main characters have been separated yet again, and the narrator is alone on board a ship bound for America, he encounters an acquaintance, "a solemn but pleasant old doctor" who tells yet another story: he had seen the narrator's wife in Marseilles a few days before the ship departed, evidently waiting for her husband to join her with their tickets. After relating this encounter, the narrator addresses V.: "This is, I gather, the point of the whole story - although if you write it, you had better not make him a doctor, as that kind of thing has been overdone. It was at that moment that I suddenly knew for certain that she had never existed at all." The reference to the doctor is surely a multi-layered allusion to both Chekhov's characters and to Chekhov himself. And the attempted erasing of the heroine is also a reversal of Chekhov's technique. In the early pages of "The Lady with the Little Dog," Anna Sergeyevna seems like a stereotypical figure whose literary predecessors include the "seduced and abandoned" girls of sentimentalism, as well as the adulterous heroines of nineteenth-century realism. Our first glimpse of her reduces her to a type, simply a lady with a dog, nameless and almost featureless, apparently interchangeable with any other lady. Throughout the story, this indistinct character, evidently a literary type, is transformed into a complex individual, and the seemingly banal plot is revealed to be a subtle and original tale. In "That in Aleppo Once. ..", Nabokov reverses this course. The narrator's wife is a character who is continually evading his and the reader's understanding - we cannot pin her down, and the more we seem to learn about her, the less we really know. Finally the narrator gives up; after attempting to describe her various possible lives, he declares that she never existed at all, that she is simply "an illusion," "a phantom" who exists only on the page. He states, "I am able to speak of her with as much detachment as I would of a character in a story (one of your stories, to be precise)." From a metaliterary angle, this is of course true; she (together with the narrator and V.) is a fictional character, after all. Nabokov has written a story that simultaneously pays tribute to Chekhov and perhaps expresses his anxiety of influence; in a sense, he lays bare the mechanics of storytelling, of narrative decisions and revision. Thus "the point of the whole story," as the narrator puts it, is the creative process itself.

\section{BIBLIOGRAPHY}

AleXAndrov, V. E., ed. (1995), The Garland Companion to Vladimir Nabokov, New York, Garland Publishing. 
BlOOM, H. (1997), The Anxiety of Influence: A Theory of Poetry, New York, Oxford University Press.

CHEKHOV, A. P. (1955), Sobranie sochinenii v 12 tomakh, Moscow, Gosudarstvennoe izdatelstvo khudozhestennoi literatury.

NABOKOV, V. (1973), Strong Opinions, New York, McGraw-Hill.

NABOKOV, V. (1981), Lectures on Russian Literature, New York, Harcourt.

NABOKOV, V. (1996), The Stories of Vladimir Nabokov, New York, Vintage.

SHRAYER, M. (2000), The World of Nabokov's Stories, Austin, University of Texas Press.

TERRAS, V. (1994), A History of Russian Literature, New Haven, Yale University Press. 